\title{
Seasonal variations in macrophytic biomass in a shallow pond at Biratnagar, Nepal
}

\author{
Bhabindra Niroula ${ }^{1 *}$ and K.L.B. Singh ${ }^{2}$ \\ ${ }^{I}$ Department of Botany, Post Graduate Campus, Tribhuvan University, Biratnagar, Nepal \\ ${ }^{2}$ R.D. and D.J. College, T.M. Bhagalpur University, Monghyr, India \\ *E-mail:niroulab@gmail.com
}

\begin{abstract}
Macrophytic biomass in a shallow pond ranged between $82.8-1134.6 \mathrm{~g} / \mathrm{m}^{2}$; $16.0-75.7 \mathrm{~g} / \mathrm{m}^{2} ; 170.6-1600.1 \mathrm{~g} / \mathrm{m}^{2}$ for emergent, submerged and free floating community, respectively. Maximum total community biomass $\left(2725.2 \mathrm{~g} / \mathrm{m}^{2}\right)$ was recorded in August with major contribution of water hyacinth. During rainy season, total phosphate $\left(\mathrm{PO}_{4}-\mathrm{P}\right)-0.17 \mathrm{mg} / \mathrm{l}$; nitrate $\left(\mathrm{NO}_{3}-\mathrm{N}\right)-0.7 \mathrm{mg} / \mathrm{l} ;$ nitrite $\left(\mathrm{NO}_{2}-\mathrm{N}\right)-0.02 \mathrm{mg} / \mathrm{l}$ and ammonia $\left(\mathrm{NH}_{3}-\mathrm{N}\right)-5.2$ $\mathrm{mg} / \mathrm{l}$; were maximum, whereas, $\mathrm{pH}(6.3)$, dissolved oxygen $(6.3 \mathrm{mg} / \mathrm{l})$ and conductivity $(184 \mu \mathrm{s} / \mathrm{cm})$; were minimum in water samples.
\end{abstract}

Key words: Macrophytes, community biomass, emergent, water quality.

\section{Introduction}

Macrophytic communities influence the structural and functional characteristics of aquatic ecosystems (Canfield et al., 1984). Aquatic habitats select the assemblage of plants, best adapted to the existing conditions (Mitsch et al., 1998). They dynamically guide the cycle of minerals and other organic compounds, thereby influencing overall biomass production of water bodies. Aquatic species occurring therein act as bio-energy sources and agents of pollution abatements (Brooks, 1989; Oliver \& Hill, 1998). Water bodies receive directly or indirectly sewage, domestic wastes, industrial effluents and agricultural run-off from the surrounding areas. Accumulation of nutrients in aquatic ecosystems leads to massive growth of macrophytes. Their control is possible through biomass utilization (Majid, 1998-99). Macrophytic biomass can be used for production of biogas, paper, fiber boards, fertilizer and fish feed. Water bodies must be assessed in terms of species composition, biomass production and water quality.

Aquatic macrophytes have been quantitatively studied in Nepal by Shrestha (2000), Burlakoti and Karmacharya (2004), Niroula and Singh (2011, 2012), and Upadhyay et al. (2011). Reddy and Sutton (1984), Sharma (1995), Khan and Shah (2010) and Jaiswal (2011) studied biomass production and water quality improvement through macrophytes in India. Present study deals with macrophytic biomass and physico-chemical properties of water of a shallow pond at Biratnagar, Nepal.

\section{Materials and Methods}

The selected pond (1.5 ha) is surrounded by cultivated land. It has seasonal variation in water

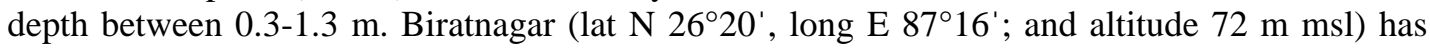
alluvial soil and tropical monsoon climate with three distinct seasons viz., winter (Nov-Feb.), summer (March-June) and rainy (July-October) in a year. The average annual rainfall is 1312 $\mathrm{mm}$, average annual minimum and maximum temperatures 14.2 and $30.6^{\circ} \mathrm{C}$, respectively. 
Samplings of aquatic macrophytes were done by harvest method using a quadrat of $50 \mathrm{~cm} \times 50$ $\mathrm{cm}$ size in adequate numbers at monthly intervals from January to December, 2009. Collected samples were washed, brought to the laboratory and after proper sorting and processing samples were oven dried to constant weight at $80^{\circ} \mathrm{C}$. Methods of Zobel et al. (1987) and APHA (1985) were adopted for determining biomass and water quality, respectively.

\section{Results and Discussion}

In total 6 aquatic plants forming three communities; emergents, free floating and submerged were in the pond (Table 1). Physico-chemical properties of the pond water showed seasonal variation (Table 2). During rainy season, total phosphate $\left(\mathrm{PO}_{4}-\mathrm{P}\right)-0.17 \mathrm{mg} / \mathrm{l}$; nitrate $\left(\mathrm{NO}_{3}-\mathrm{N}\right)$ $0.7 \mathrm{mg} / \mathrm{l}$; nitrite $\left(\mathrm{NO}_{2}-\mathrm{N}\right)-0.02 \mathrm{mg} / \mathrm{l}$ and ammonia $\left(\mathrm{NH}_{3}-\mathrm{N}\right)-5.2 \mathrm{mg} / \mathrm{l}$ were maximum, whereas, water $\mathrm{pH}(6.3)$, dissolved oxygen $(6.3 \mathrm{mg} / \mathrm{l})$, and conductivity $(184 \mu \mathrm{s} / \mathrm{cm})$ were minimum. Water $\mathrm{pH}$ (10.4) and dissolved oxygen $(10.3 \mathrm{mg} / \mathrm{l})$, recorded maximum during winter season. Higher concentrations of ammonia, nitrite, nitrate and total phosphate in the rainy season might be attributed to input from running water, surface run-off and mineralization of organic matter. Maximum electrical conductivity $(603 \mu \mathrm{s} / \mathrm{cm})$ during summer season might be due to the accumulation of chlorides and sulphates of calcium, magnesium, sodium and potassium salts in decreasing water level of the pond (Upadhyay et al., 2012).

Table 1. Macrophytic communities of the pond.

\begin{tabular}{|c|c|c|c|}
\hline Species/Community & Family & Common name & Local name \\
\hline \multicolumn{4}{|l|}{ Emergent } \\
\hline $\begin{array}{l}\text { Alternanthera philoxeroides Griseb } \\
\text { Ipomoea carnea Jacq. subsp. fistulosa }\end{array}$ & Amaranthaceae & Alligator weed & Jaljamboo \\
\hline (Mart. ex Choicy) D.F. Austin & Convolvulaceae & - & Thetar \\
\hline Typha angustifolia $\mathrm{L}$. & Typhaceae & Cat tail & Pater \\
\hline \multicolumn{4}{|l|}{ Free floating } \\
\hline Eichhornia crassipes (Mart.) Solms. & Pontederiaceae & Water hyacinth & Jalkumbhi \\
\hline \multicolumn{4}{|l|}{ Summerged } \\
\hline Chara schweinitzii A. Braun & Characeae & Muskgrass & Leu \\
\hline Potamogeton crispus L. & Potamogetonaceae & Curlyleaf pondweed & Panikhar \\
\hline
\end{tabular}

Table 2. Seasonal variations in physico-chemical properties of the pond.

\begin{tabular}{lccc}
\hline Parameter & Winter & Summer & Rainy \\
\hline Water depth $(\mathrm{cm})$ & $34-48$ & $32-44$ & $90-135$ \\
Temperature $\left({ }^{0} \mathrm{C}\right)$ & 22.7 & 26.4 & 27.3 \\
Transparency $(\mathrm{cm})$ & 14 & 16 & 8 \\
pH & 7.9 & 6.5 & 6.3 \\
Dissolved oxygen $(\mathrm{mg} / \mathrm{l})$ & 10.4 & 7.8 & 6.3 \\
Conductivity $(\mu \mathrm{s} / \mathrm{cm})$ & 249 & 603 & 184 \\
Ammonia $\left(\left(\mathrm{NH}_{3}-\mathrm{N}\right) \mathrm{mg} / \mathrm{l}\right.$ & 3.5 & 3.3 & 5.2 \\
Nitrate $\left(\left(\mathrm{NO}_{3}-\mathrm{N}\right) \mathrm{mg} / \mathrm{l}\right.$ & 0.49 & 0.08 & 0.7 \\
Nitrite $\left(\left(\mathrm{NO}_{2}-\mathrm{N}\right) \mathrm{mg} / \mathrm{l}\right.$ & 0.002 & 0.002 & 0.02 \\
Kjeldhal Nitrogen $(\mathrm{mg} / \mathrm{l})$ & 2.94 & 3.4 & 4.33 \\
Total Phosphate $\left(\mathrm{PO}_{4}-\mathrm{P}\right) \mathrm{mg} / \mathrm{l}$ & 0.05 & 0.09 & 0.17 \\
\hline
\end{tabular}

Monthly variations in percent contribution by dry biomass of total macrphytic community; emergent, submerged and free floating communities are shown in table 3. 
Table 3. Monthly variation in dry biomass $\left(\mathrm{g} / \mathrm{m}^{2}\right)$ of aquatic communities in a shallow pond. (mean $\pm \mathrm{SE}$ ), figure in parenthesis represents percent contribution.

\begin{tabular}{lllll}
\hline \multirow{2}{*}{ Month } & \multicolumn{4}{c}{ Community biomass } \\
\cline { 2 - 5 } & Emergent & Submerged & Free floating & Total \\
\hline January & $300 . \pm 7.7(56)$ & $16.0 \pm 1.7(3)$ & $220.0 \pm 6.6(41)$ & $536.0 \pm 10.3$ \\
February & $82.8 \pm 4.1(25.1$ & $75.7 \pm 3.8(23)$ & $170.6 \pm 5.8(51.8)$ & $329.1 \pm 8.1$ \\
March & $370.6 \pm 8.6(47.6)$ & $62.1 \pm 3.5(8)$ & $346.6 \pm 8.3(44.4)$ & $779.3 \pm 12.4$ \\
April & $479.2 \pm 9.7(48)$ & - & $520.0 \pm 10.2(52)$ & $999.2 \pm 14.1$ \\
May & $313 \pm 7.9(26.8)$ & - & $856.0 \pm 13.1(73.2)$ & $1169.3 \pm 15.2$ \\
June & $618.5 \pm 11.1(34.4)$ & - & $1034.6 \pm 14.3(65.3)$ & $1653.1 \pm 18.1$ \\
July & $549.2 \pm 10.4(34.7)$ & - & $1034.6 \pm 14.3(65.3)$ & $1583.8 \pm 17.7$ \\
August & $1134.6 \pm 15.1(41.6)$ & - & $1590.6 \pm 18.3(58.4)$ & $2725.2 \pm 23.3$ \\
September & $914.5 \pm 13.5(49.5)$ & - & $932.6 \pm 13.6(50.5)$ & $1847.1 \pm 19.2$ \\
October & $1000.0 \pm 14.1(52)$ & - & $924.0 \pm 13.5(48)$ & $1924.0 \pm 19.6$ \\
November & $526.6 \pm 10.2(24.8)$ & - & $1600.1 \pm 17.8(75.2)$ & $2126.7 \pm 20.6$ \\
December & $98.3 \pm 4.4(13.8)$ & - & $612.0 \pm 11.1(86.2)$ & $710.3 \pm 11.9$ \\
\hline
\end{tabular}

Emergents had maximum and minimum biomass on October $\left(1000.0 \mathrm{~g} / \mathrm{m}^{2}\right)$ and February $(82.2$ $\mathrm{g} / \mathrm{m}^{2}$ ) contributing 52 and $25 \%$ of the total community, respectively. Free floating had maximum $\left(1600.1 \mathrm{~g} / \mathrm{m}^{2}\right)$ and minimum $\left(170.6 \mathrm{~g} / \mathrm{m}^{2}\right)$ during November and February contributing $75.2 \%$ to $51.8 \%$, of the total community biomass, respectively. However, percent contribution was maximum $(86.2 \%)$ in December. The free floating Eichhornia crassipes dominated community biomass in all months except January, March and October. Submerged were recorded only during winter and early summer month (March), being maximum during February $\left(75.7 \mathrm{~g} / \mathrm{m}^{2}\right)$ and minimum during January $\left(16.02 \mathrm{~g} / \mathrm{m}^{2}\right)$. Upadhyay et al. (2012) recorded $452-1238 \mathrm{~g} / \mathrm{m} 2$ dry biomass in deep water and elongated depressions and $748.2 \mathrm{~g} / \mathrm{m}^{2}$ in a public pond surrounded by agricultural land at Biratnagar township. Among the dominant aquatic macrophytes, dry biomass ranged 4.6-202.9 g/m $\mathrm{m}^{2}$ and $9.3-1120.5 \mathrm{~g} / \mathrm{m}^{2}$ for Alternanthera philoxeroides and Eichhornia crassipes, respectively in Morang district, eastern Nepal (Niroula \& Singh, 2012). Rai and Sharma (1991) reported biomass from a eutrophic pond of Bihar (India), which ranged 812.5$1170 \mathrm{~g}$ dry wt. $/ \mathrm{m}^{2}$. Maximum total community biomass $\left(2725.2 \mathrm{~g} / \mathrm{m}^{2}\right)$ was in August with major contribution of water hyacinth.

Macrophytic community biomass in the shallow pond may be utilized in the nearby agricultural land as compost. Manipulation of biomass for compost and biogas production could be a cheap and viable solution for nutrient cycling between aquatic and terrestrial ecosystems. Water hyacinth is a troublesome invasive alien species with prolific growth rate that absorb nutrients from the water body and becomes source of potash, phosphorus and nitrogen in the agriculture (Gopal, 1987). Chemical composition is correlated with the chemical status of the water and maximum nutrients are absorbed at the time of maximum growth (Denton, 1967).

\section{Acknowledgements}

Thanks are due to Professor Dr. S.N. Jha, Head, Department of Botany, Post Graduate Campus, T.U. Biratnagar, Nepal for providing laboratory facilities and encouragements, and the UGC, Nepal for financial support. 


\section{References}

Ambasht, R. S. 1971. Ecosystem study of a tropical pond in relation to primary production of different vegetation zones. Hydrobiologia 12: 57-61.

APHA, 2005. Standard methods for examination of water and waste water. $20^{\text {th }}$ Ed., USA.

Brooks, J. M. 1989. An overview of ecological functions and economic values of wetlands. In: Wetland ecology and conservation: Emphasis in Pennsylvania (Eds. S.K. Majumdar, R.P. Brooks, F.J. Brenner \& R.W. Tiner). The Pennsylvania Academy of Science, Easton. p. 395.

Burlakoti, C. \& S.B. Karmacharya. 2004. Quantitative analysis of macrophytes of Beeshazar Tal, Chitwan, Nepal. Himalayan Journal of Sciences 2(3): 37-41.

Canfield, D.E., J.V. Chapman \& J.R. Jones. 1984. Assessing the trophic status of lakes with aquatic macrophytes. Lakes and Resrv. Manang. 1: 446-450.

Denton, J.B. 1967. Certain relationship between the chemical composition of aquatic plants and water quality. Proc. $20^{\text {th }}$ Weed Conf.: 354-362.

Gopal, B. 1987. Water hyacinth. Elsevier Science Publishers, New York.

Jaiswal, Sadhana. 2011. Growth and nutrient accumulation by Eichhornia crassipes (Mart.) Solms in Robertson Lake, Jabalpur, India. Ecoprint 18: 91-100.

Khan, M.A. \& M.A. Shah. 2010. Studies on biomass changes and nutrient lock up efficiency in a Kashmir Himalayan wetland ecosystem, India. Journal of ecology and Natural environment 2(8): 147-153.

Mazid, F.Z. 1998-99. Aquatic weeds: Utility and management. Agro Botanica, Bikaner, India.

Mitsch, W.J., X. Wu, R.W. Nairn, P.E. Weihe, N. Wang, R. Deal \& C.E. Boucher. 1998. Creating and restoring wetlands: A whole ecosystem experiment in self-design. BioScience 48: 10191030. http://dx.doi.org/10.2307/1313458

Niroula, B. \& K.L.B. Singh 2011. Seasonal Variation in Importance Value Index (IVI), Diversity Indices and Biomass of aquatic macrophytes at Biratnagar and adjoining areas, eastern Nepal. Nepalese Journal of Biosciences 1: 1-7.

Niroula, B. \& K.L.B. Singh. 2012. Phytosociology of freshwater macrophytes found in Morang district, eastern Nepal. Journal of Indian Botanical Society 91(4): 333-337.

Oliver, J.C. \& R.J. Hill, 1998. Foreword. In: Ecology of wetlands and associated systems. (Majumdar, S.K., E.W. Miller \& F.J. Brenner Eds.). The Pennsylvania Academy of Science, Easton, P.A. pp: $1-3$.

Reddy, K.R. \& D.L. Sutton. 1984. Water hyacinths for water quality improvement and biomass production. Journal of environmental quality 13(1): 1-8. http://dx.doi.org/10.2134/jeq1984. 1311

Sharma, U.P. \& D.N. Rai, 1989. Biomass of hydrophytes in an eutrophic pond of Bhagalpur (Bihar). J. Freshwater Biol. 1(2): 173-176.

Sharma, U.P. 1995. Role of macrophytes in the ecosystem of Kawar Lake wetland (Begusarai), Bihar, India. J. Freshwater Biol. 7(2): 123-128.

Shrestha, P. 2000. Vegetation analysis of aquatic macrophytes by using line intercept method in lake Phewa, Pokhara, Nepal. Ecoprint 7(1): 7-14.

Upadhyay, B.P., S. Jha, U. Koirala \& B. Niroula. 2011. Inventory of ten aquatic habitats of Biratnagar township, Nepal. Geobios 38(4): 285-290.

Zobel, D.B., P.K. Jha, U.K. Yadav \& M.J. Behan. 1987. A practical manual for ecology. Ratna Book Distributors, Kathmandu. 